\title{
RESEARCH
}

\section{Directed Integration of the Physical and Genetic Linkage Maps of Swine Chromosome 7 Reveals that the SLA Spans the Centromere}

\author{
Timothy P.L. Smith, ${ }^{1,4}$ Gary A. Rohrer, ${ }^{1}$ Leeson J. Alexander, ${ }^{1}$ \\ Deryl L. Troyer, ${ }^{2}$ Kathleen R. Kirby-Dobbels, ${ }^{2}$ Mark A. Janzen, ${ }^{3}$ \\ Dean L. Cornwell, ${ }^{2}$ Charles F. Louis, ${ }^{3}$ Lawrence B. Schook, ${ }^{3}$ and \\ Craig W. Beattie ${ }^{1}$
}

'U.S. Department of Agriculture (USDA), Agricultural Research Service, Roman L. Hruska U.S. Meat Animal Research Center (MARC), Clay Center, Nebraska 68933; ${ }^{2}$ Department of Anatomy and Physiology, College of Veterinary Medicine, Kansas State University, Manhattan, Kansas 66506;

${ }^{3}$ Deptartment of Veterinary Pathobiology, University of Minnesota, St. Paul, Minnesota 55108

The first integrated physical and genetic linkage map encompassing the entire swine chromosome 7 (SSC7) reveals that the porcine MHC (SLA) spans the centromere. A SLA class II antigen gene lies on the $q$ arm, whereas class I and III genes lie on the $p$ arm, suggesting that the presence of a centromere within the SLA does not preclude a functional complex. The SLA appears smaller than other mammalian MHC, as the genetic distance across two class I, three class II, and three class III SLA gene markers is only $1.1 \mathrm{cM}$. There are significant variations in recombination rates as a function of position along the chromosome, and the SLA lies in the region with the lowest rate. Furthermore, the directed integration approach used in this study was more efficient than previous efforts that emphasized the screening of large insert libraries for random microsatellites.

Genetic maps of livestock species are currently being developed to provide a worldwide resource for mapping quantitative trait loci, comparative mapping in evolutionary studies, and mapping of pertinent loci in animal models of human disorders. These objectives require a framework of informative markers that can be genotyped economically. Integration of this framework with a cytogenetic map allows evaluation of coverage, genome size, and recombination rates along the chromosome, as well as establishing syntenic relationships among species. Two linkage maps of swine chromosome 7 (SSC7) have been reported, one that includes 11 (Edfors-Lilja et al. 1993; Archibald et al. 1995) and one with 17 (Rohrer et al. 1994) microsatellite markers. The two maps have only one marker in common, and both contain intervals $>30 \mathrm{cM}$. The cytogenetic map includes only four relatively low resolution assignments of linked markers with $\sim 30 \%$ coverage (Ed-

\footnotetext{
${ }^{4}$ Corresponding author.
}

E-MAIL smith@map.marc.usda.gov; FAX (402)762-4390.
fors-Lilja et al. 1993; Yerle et al. 1995), making integration of the physical and genetic maps difficult.

SSC7 contains the major histocompatibility complex (MHC) gene complex which lies on human chromosome $6 \mathrm{p} 21.3$; a group of metabolic enzyme genes [mannose phosphate isomerase, aminopeptidase N (ANPEP), and muscle pyruvate kinase] found on human chromosome 15; and three genes (nucleoside phosphorylase, $\alpha 1$ antitrypsin, immunoglobulin heavy chain) located on human chromosome 14 (for review, see O'Brien et al. 1993; Johansson et al. 1995). The SLA is the subject of intense interest owing to its role in immune function and reported influence on reproductive and performance traits (Kristensen and de Weck 1980; Jung et al. 1989; Mallard et al. 1989; Vaiman 1989; reviewed in Schook et al. 1995). In addition, loci in or closely linked to the SLA affect penetrance of malignant melanoma in a swine model for this disease (Tissot et al. 1987).

The SLA was originally assigned to the $\mathrm{q}$ arm 


\section{T. SMITH ET AL.}

of SSC7 proximal to 7q2.1 by in situ hybridization (Geffrotin et al. 1984) using a radiolabeled full-length human class I gene probe (HLA-B7; Sood et al. 1981). Subsequent analysis using the same probe (Echard et al. 1986) or a full-length porcine class I gene probe (PD1A; Rabin et al. 1985; Singer et al. 1988) reported the SLA to lie near the centromere in the region $7 \mathrm{p} 1.4-\mathrm{q} 1.2$ and $7 \mathrm{p} 1.2-\mathrm{q} 1.2$, respectively. The low resolution of these assignments could result from a dispersed distribution of SLA genes that crosshybridize with the selected probe; however, a limited physical map of the SLA produced via pulsed field gel electrophoresis (PFGE) suggests the complex is $\sim 2 \mathrm{Mb}$ in width (Xu et al. 1992). Although swine appear to have fewer class I genes than other mammalian species studied, at least seven genes hybridized to an HLA probe (Singer et al. 1988), which may also affect the resolution of the physical assignments. A more recent analysis using a radiolabeled class III gene [tumor necrosis factor $\alpha$ (TNF $\alpha)$; Kuhnert et al. 1991] that appears to be single copy in the swine genome reported an assignment to 7q1.1-p1.1 (Solinas et al. 1992).

We have used cosmid probes containing markers for each class of SLA gene to obtain physical assignments by fluorescence in situ hybridization (FISH), which has a higher resolution than is provided by radiolabeled probes (Lichter et al. 1990). We observe that the SLA spans the centromere of SSC7, making swine unique among mammals studied to date. In addition, we present a linkage group on SSC7 that includes a total of 55 polymorphic markers, with no interval $>17 \mathrm{cM}$. Cosmids bearing specific microsatellites in the linkage group are used to integrate the physical and genetic linkage maps, and demonstrate that the map encompasses the entire chromosome.

\section{RESULTS}

\section{Linkage Analysis}

Our laboratory identified 38 porcine microsatellite markers (Table 1; Rohrer et al. 1994; L.J. Alexander, G.A. Rohrer, C.W. Beattie, in prep.) that form a linkage group containing the TNF $\beta$ and ANPEP genes (Olsen et al. 1989; Kuhnert et al. 1991), which have been localized to porcine chromosome 7p1.1-q1.1 (TNFß) and 7q1.1-q2.2 (ANPEP) by in situ hybridization (Poulsen et al.
1991; Solinas et al. 1992). We also genotyped 8 additional microsatellites from a group of 11 reported previously in SSC7 linkage groups (EdforsLilja et al. 1993; Ellegren et al. 1994a; Archibald et al. 1995) to facilitate map comparisons. All markers were genotyped across the USDA MARC reference population (Rohrer et al. 1994).

The linkage analysis also includes seven restriction fragment length polymorphisms (RFLP) markers that represent the three classes of SLA genes. For this analysis we developed highly specific, relatively short probes from six cloned SLA genes (see Methods). Two class I probes (PD6 and PD7; Satz et al. 1985) hybridized to two bands corresponding to each of the two alleles present in the reference population DNA digested with BglII (PD6) or EcoRI (PD7), providing two unambiguous class I markers for linkage analysis (Fig. 1a,b). Two class II probes (DRB and DQA; Pratt et al. 1990) were derived that displayed extremely low cross-reactivity relative to full-length probes (data not shown). These probes hybridized to one or two bands for each of eight alleles found in the reference population DNA digested with the enzymes BamHI (DRB) or MspI (DQA; Fig. 1c,d). A third class II gene (DQB) was genotyped by PCRRFLP using the enzyme HaeIII as described (Shia et al. 1995). The class III probe Bf revealed a polymorphism in the reference DNA digested with TaqI as described previously (Peelman et al. 1991; data not shown). A second class III gene, CYP21 (Geffrotin et al. 1991), was also polymorphic on TaqI-digested DNA (Fig. 1e). A third class III gene, TNF $\beta$, was genotyped using an adjacent polymorphic microsatellite (Kuhnert et al. 1991; Rohrer et al. 1994). The RFLPs followed Mendelian inheritance patterns in all cases (data not shown).

Linkage analysis was performed using CRIMAP 2.4 (Green et al. 1989) as described (Rohrer et al. 1994). Markers were aligned in the order that maximized the LOD. The genotyping error rate was extremely low $(0.1 \%)$, with only five double crossovers identified by the CHROMPIC option of the program in $>6000$ informative meioses. The linkage group flanks $151 \mathrm{cM}$ of SSC7 and includes 34 intervals with recombination fractions $>0$, as shown in the idiogram in Figure 2 . The average non-zero interval is $4.4 \mathrm{cM}$, with only three intervals of $>10 \mathrm{cM}$ (none larger than $17 \mathrm{cM})$.

Figure 2 provides complete data on the linkage analysis in the form of a heterozygosity diagram joined to the map idiogram. All pertinent information with respect to levels of heterozygos- 
MAP OF SSC7 REVEALS SLA SPANS CENTROMERE

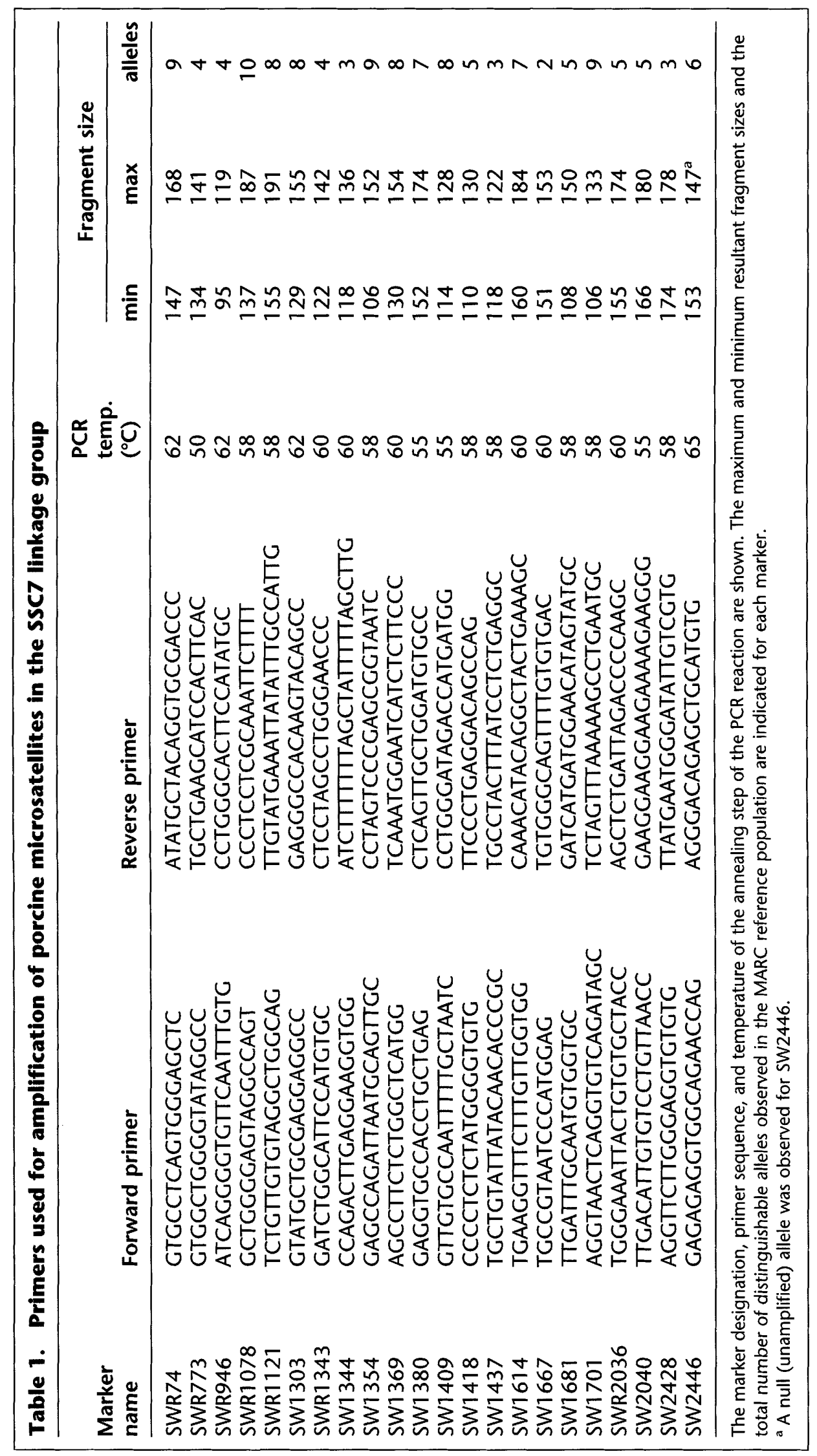



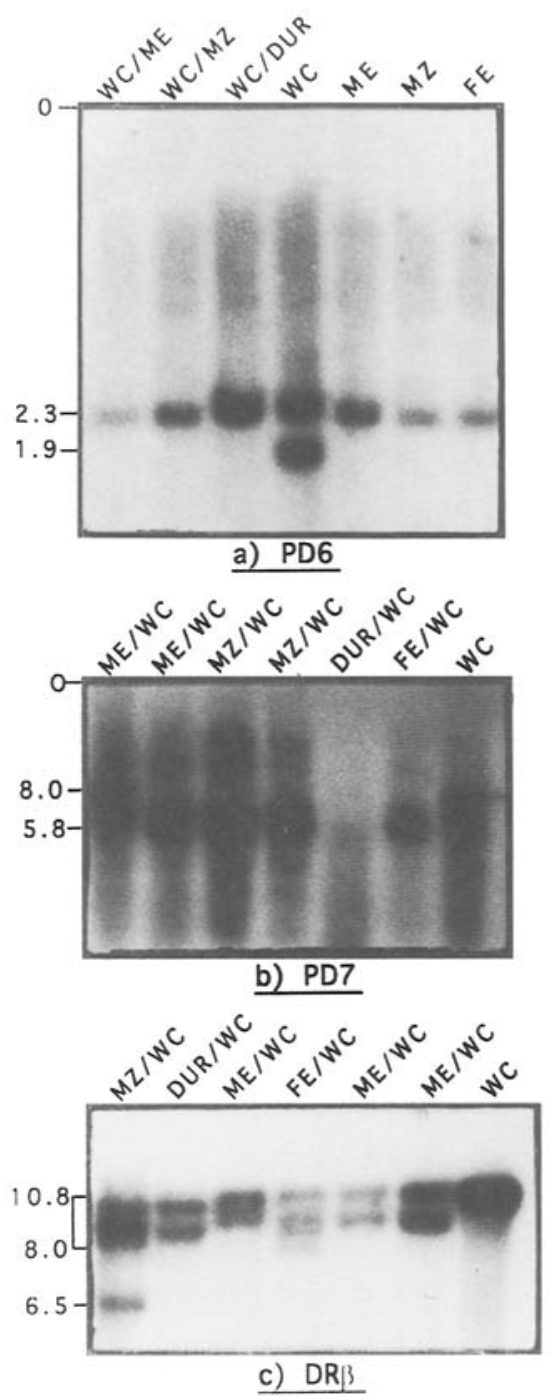

Figure 1 RFLP analysis of SLA genes. The indicated SLA probes were hybridized to Southern blots of porcine DNA digested with the following restriction enzymes: Bgfl (a); EcoRI (b); BamHI (c); Mspl (d); Taql (e). Animal breed type is indicated above each lane: (WC) White composite; (MZ) Minzhu; (ME) Meishan; (FE) Fengjing; (DUR) Duroc. Numbers to the left of each autoradiograph indicate the approximate size of the polymorphic bands in kilobases. (O) The origin of the gel.

ity, numbers of informative meioses, and numbers of coinformative meioses for any marker or set of markers in the linkage group can be calculated from the data. For example, it can be seen that the two WC boars, two Duroc-WC sows (a and $\mathrm{b}$ ), and six Chinese-WC sows (c-h) are heterozygous for $50 \%, 60 \%$, and $71 \%$ of the SSC7 markers, respectively. In addition, the number of potential informative meioses for each marker can be calculated by summing the number of offspring for each heterozygous parent. The actual number of meioses (equal to or slightly lower than the potential depending on genotyping difficulties) used to calculate genetic distance is shown to the right of the symbols; the average is 111 meioses per marker.

The data in Figure 2 can also be used to calculate map resolution, which is determined by the ability to correctly order markers. A set of three closely spaced markers can be ordered with respect to one another only when recombination occurs between them, whereas the probability of observing a recombination event diminishes with decreasing genetic distance. The average number of coinformative meioses required to observe recombination between markers spaced $5 \mathrm{cM}$ apart is 100 , and 440 for markers spaced $1 \mathrm{cM}$ apart (J. Keele, unpubl.). Thus, the data in Figure 2 can be used to predict which markers can be definitively ordered in relation to one another, by summing the number of offspring from parents heterozygous for any group of three or more markers with this minimum spacing. For example, SW1681 at $65 \mathrm{cM}$, SWR2036 at $70 \mathrm{cM}, \mathrm{SW} 732$ at $77 \mathrm{cM}$, and SW2040 at $82 \mathrm{~cm}$ are coinformative for 133 meioses (81 from boar 2 and 13, 12,13 , and 14 from dams a, d, e and $\mathrm{f}$, respectively). This number is sufficient to conclude that these four markers, which span a 17-cM interval, are correctly ordered with respect to one another. The resolution of the SSC7 map, which varies along the linkage group with the density and informativeness of markers, can thus be calculated for any interval of interest.

A single crossover within the SLA was observed in 81 meioses that were informative across the complex. One of the offspring from boar 2 received paternal alleles for SW1409, TNF $\beta$, PD6, 


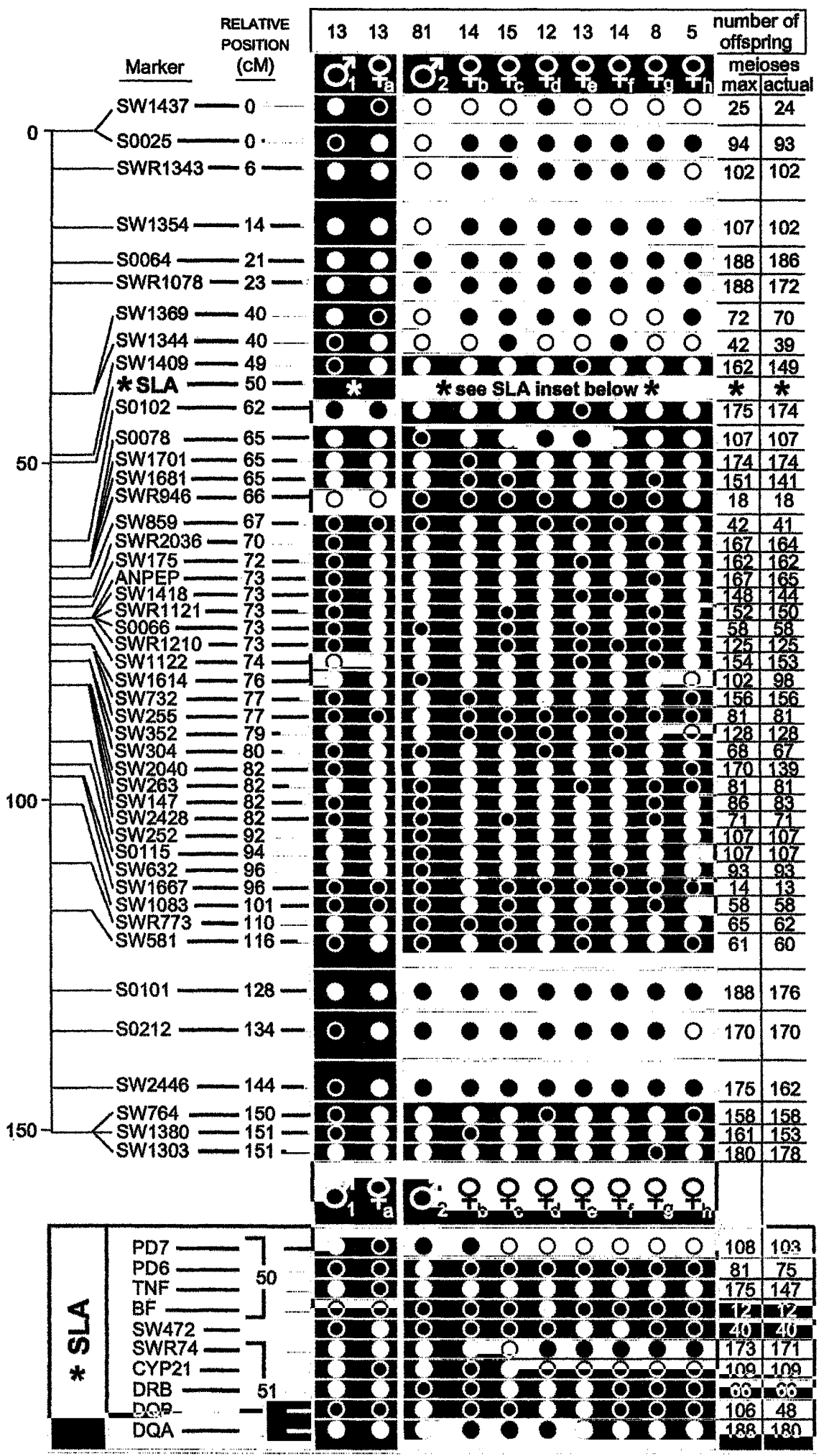

Figure 2 (See following page for legend.) 


\section{T. SMITH ET AL.}

and PD7 from one paternal grandparent, and paternal alleles for SWR74, CYP21, DQA, DQB, and S0102 from the other paternal grandparent. This crossover allowed us to order the SLA genes as shown, placing the class III genes between the class I and II genes, and to orient the group with the class I genes closest to the telomere of the $p$ arm. Other orders or orientations gave lower scores by $>3$ LOD. Our result is in agreement with previous reports of SLA gene order and orientation (Geffrotin et al. 1991; Edfors-Lilja et al. 1993). The crossover results in a calculated genetic distance of $1.1 \mathrm{cM}$ between the ends of the SLA, close to the value reported previously (1.5 cM, Ellegren et al. 1994a). Assuming that one cM represents $\sim 1 \mathrm{Mb}$, the data suggest that the SLA is in the range of 1-2 million bp, smaller than the MHC of humans (3.5-5 Mb; Carroll et al. 1987; Dunham et al. 1987; Lawrance et al. 1987). The smaller apparent size of the SLA is within the $2000 \mathrm{~kb}$ estimated by PFGE (Xu et al. 1992) and may be attributable, in part, to the lower number of class I genes found in swine (Singer et al. 1988).

The PiGMaP consortium reported recently a linkage group flanking $170 \mathrm{cM}$ (sex averaged) on SSC7 that includes 11 microsatellites (Archibald et al. 1995). In this linkage group, there is an average intermarker distance of $17 \mathrm{cM}$ between microsatellite markers, with two gaps of $30 \mathrm{cM}$. Comparison of common markers between this map and our linkage group (Fig. 3) shows that the marker order is identical, supporting marker order in both maps. The primary difference is the size of the two maps, which results from substantially larger intervals between the three microsat- ellite markers closest to the q-arm telomere in the consortium map (S0066, S0115, and S0212). We note that the majority of the five nonmicrosatellite markers in these intervals on the consortium map are of low informativeness (three of five) and/or are protein polymorphisms (three of five), which may be more prone to genotyping error that can inflate the calculated genetic interval.

\section{Cytogenetic Analysis}

Previous physical assignments of polymorphic microsatellite loci on SSC7 were limited to three markers in a $22-\mathrm{cM}$ region in the vicinity of the centromere (Rabin et al. 1985; Echard et al. 1986; Poulsen et al. 1991; Solinas et al. 1992; Ellegren et al. 1994a; Yerle et al. 1995). Two RFLP markers have been physically assigned but only expand the physical map to $25 \mathrm{cM}$ (Geffrotin et al. 1984; Rabin et al. 1985; Echard et al. 1986; Yerle et al. 1995). To provide a more comprehensive integration of the physical and genetic linkage maps and assess the chromosomal coverage of our linkage group, we used a modification of an iterative screening technique (Israel 1993; T.P.L. Smith, unpubl.) to isolate cosmid clones bearing specific microsatellites or genes for assignment by FISH.

First, to provide comparison with published cytogenetic maps (for review, see Yerle et al. 1995), cosmids bearing the previously assigned genes ANPEP and TNF $\beta$ were isolated. As shown in Figure 4, $a$ and $b$, these cosmids mapped to $7 \mathrm{q} 1.5$ and $7 \mathrm{p} 1.1$, respectively. This is consistent with published data (Poulsen et al. 1991; Solinas et al. 1992), and refines the assignments of these two genes. In addition, we isolated a cosmid bear-

\footnotetext{
Figure 2 Linkage analysis of markers on SSC7. An idiogram of marker order and interval size that maximizes the overall LOD score is shown at left. A scale (in CM) is given for reference, using the SW1437/S0025 locus as $0 \mathrm{cM}$. The exact calculated position is shown at the right of each marker. The SLA locus represents 10 markers, shown in a separate box at the bottom. The positions of SLA markers are given in brackets to indicate the absence of recombination between sets of markers. Marker SW472 lies within or near the SLA, but its exact position is uncertain because it was not informative for the chromosome containing the crossover (see text). Thus, SW472 has 0 recombination with all other nine SLA markers and cannot be grouped with either set of SLA markers. It is shown in the middle of the complex solely to reflect this fact. A heterozygosity diagram for the parents of the reference population is shown at the right of the idiogram. The individual parents are represented by sex symbols, with the number of offspring from each shown along the top. Boar 1 was mated only to sow $a$, whereas boar 2 was mated to sows $b-h$. Both boars were WC; sows $a$ and $f$ were WC/Minzhu; $b, e$, and $h$ were WC/Meishan; $d$ was a WC/Fengjing; $c$ and $g$ were a WC/Duroc. A circle beneath each parent identifies each of the 55 markers in the linkage group. (O) Heterozygous parent; $(O)$ homozygous parent. The total number of informative meioses for each marker used in calculating the linkage is shown for each marker at the far right (actual meioses) and is equal to or less than the number of offspring from heterozygous parents (max meioses) (see text).
} 


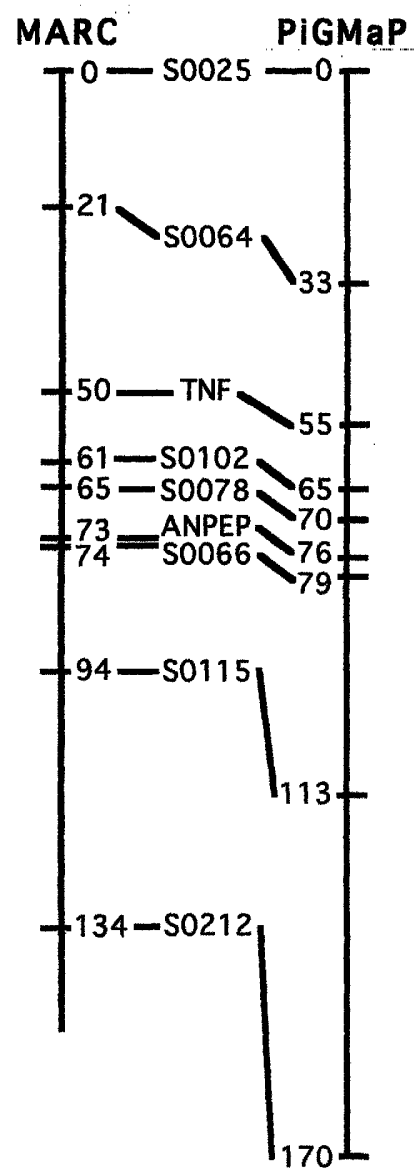

Figure 3 Comparison of MARC linkage map with the PiGMaP consortium map (Archibald et al. 1995). Markers common to both maps are shown with their calculated relative positions.

ing marker SWR74 that lies within the SLA near TNFB, which was assigned to 7pcen (Fig. 4c).

Chromosomal coverage was then assessed with cosmids bearing microsatellites at both extremes of the linkage group. Marker SW1437 maps to 7pter (Fig. 4d), and SW764 to 7qter (Fig. 4e). A third cosmid bearing marker SW2446 was isolated during a random screen of a cosmid library for microsatellites (L.J. Alexander, D.L. Troyer, G.A. Rohrer, T.P.L. Smith, L.B. Schook, and C.W. Beattie, unpubl.) and maps to the boundary between 7 q2.5 and 7 q2.6 (Fig. 4 f). This demonstrates that the linkage group spans the length of the chromosome and suggests that the sex-averaged genetic length of the chromosome is $\sim 151 \mathrm{cM}$.

To examine recombination rate as a function of position along the chromosome, two additional microsatellites that lie along the $\mathrm{q}$ arm
MAP OF SSC7 REVEALS SLA SPANS CENTROMERE

were isolated. Marker SW255 maps to 7q2.1 (Fig. $4 \mathrm{~g}$ ) and SW632 to 7q2.4 (Fig. 4h). These assignments were used to construct an integrated physical and genetic linkage map (Fig. 5). The short arm comprises approximately one-third of the chromosome, containing $50 \mathrm{cM}$ of the linkage group (SW1437-SWR74). The central third lies in the interval between 7 pcen and $7 \mathrm{q} 2.1$, which includes $27 \mathrm{cM}$ (SWR74-SW255). The bottom third of the chromosome, 7q2.1-q2.6, spans a significantly larger genetic interval of $73 \mathrm{cM}$, demonstrating that recombination rates vary as a function of position along the chromosome. The genetic distance between SWR74 (7pcen) and SW632 (7q2.4), which includes $75 \%-85 \%$ of the $\mathrm{q}$ arm, is only $46 \mathrm{cM}$, whereas the remaining $15-$ $25 \%$ of the arm between SW632 and SW764 is 54 $\mathrm{cM}$ in length. We conclude that there is a significant increase in the rate of recombination in the vicinity of 7q2.4-2.6. The recombination rate in the vicinity of the SLA is much lower (Figs. 2 and 5).

Finally, to determine the position and physical extent of the SLA, cosmids bearing SLA class I (PD6), or class II (DQB) genes were isolated. The class II cosmid mapped to the $\mathrm{q}$ arm next to the centromere (Fig. 4i), while the class I cosmid mapped to the $p$ arm (Figure $4 \mathbf{j}$ ) as did the class III gene TNF $\beta$ (Fig. 4b; see also SWR74, Fig. 4c). Thus, the major histocompatibility complex of the pig is interrupted by the centromere on SSC7.

\section{DISCUSSION}

\section{Linkage Map}

The genetic linkage map of SSC7 represents the highest density map of a livestock chromosome to date, with an average interval of $2.7 \mathrm{cM}$. The 48 microsatellite markers are spread continuously along the chromosome, supporting the assumption that dinucleotide repeats are dispersed randomly throughout the porcine genome. The average number of informative meioses for each marker in our reference population (111) is sufficient to order markers with a resolution of $5 \mathrm{cM}$ (J. Keele, unpubl.), although the resolution varies along the linkage group with marker density and informativeness. This degree of resolution is sufficient to be useful in marker-assisted selection (MAS) programs but is too coarse for efficient positional cloning. However, the application of these markers in resource populations currently 


\section{T. SMITH ET AL.}
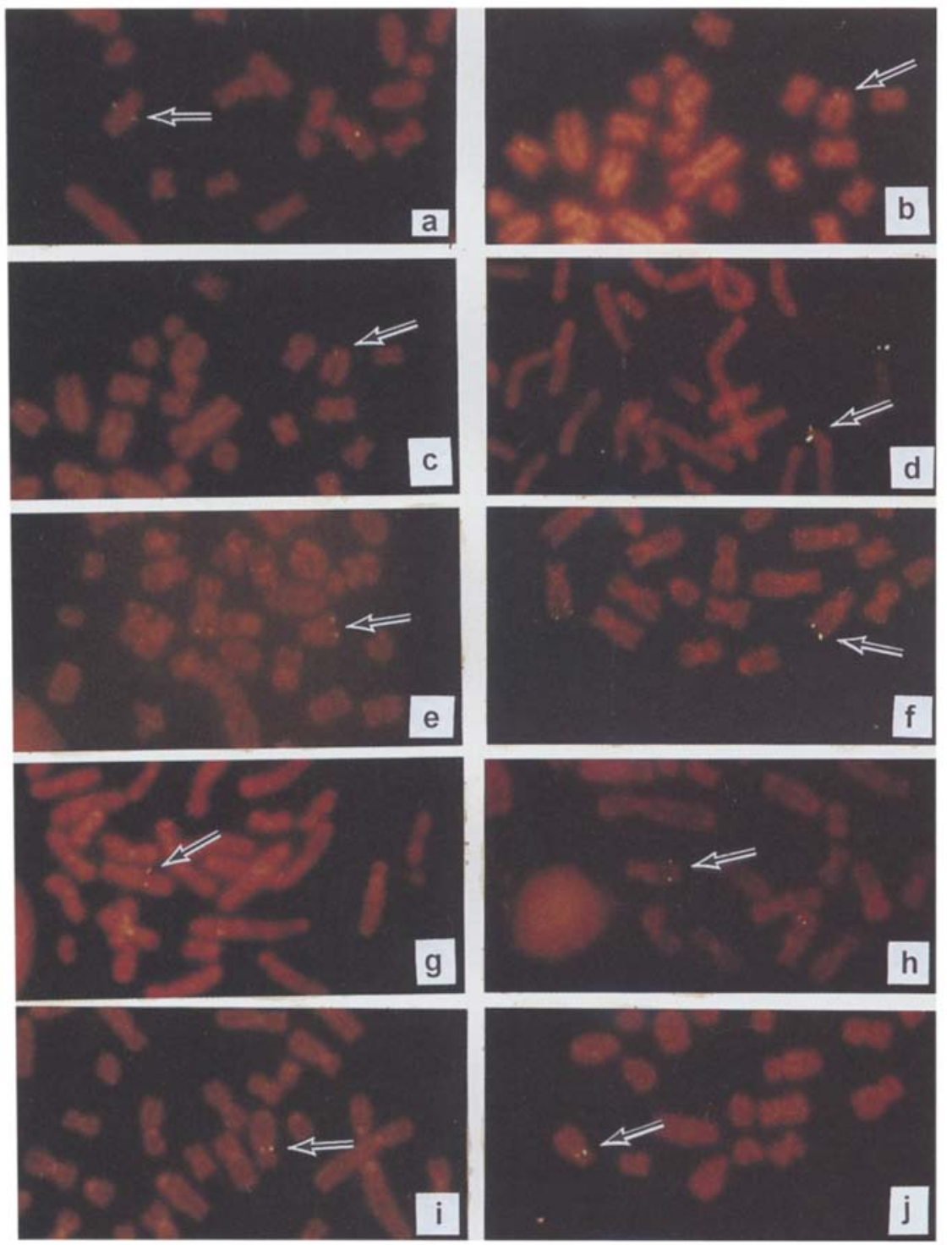

Figure 4 FISH analysis of cosmids carrying selected markers from the SSC7 linkage group. Representative partial metaphase spreads hybridized with fluorescent cosmid DNA for markers along the length of the chromosome. The cosmids used and their assignments are (a) ANPEP, q1.5; $(b)$ TNF $\beta, \mathrm{p} 1.1 ;(c)$ SWR74, pcen; (d) SW1437, pter; (e) SW764, qter; ( $f$ ) SW2446, border between q2.5-2.6; (g) SW255, q1.6; (h) SW632, q2.4; (l) DQB, q1.1; (l) PD6, p1.1.

being mapped for quantitative trait loci (QTL) will greatly increase the number of informative meioses, with a concomitant increase in the resolution of the map. As genotypic data for these populations become available, positional cloning of important loci on SSC7 will become a realizable goal.

We believe that heterozygosity diagrams such as that of Figure 2 will be generally useful to laboratories undertaking MAS in resource populations. The advantage of this type of display is direct access to the full data set for all markers on a chromosome. The standard ideogram on the left indicates which areas of the chromosome have sufficient marker density for high resolution mapping. The data in the heterozygosity diagram that is joined to the ideogram can be used to calculate coinformative meioses between any two markers being considered for use in mapping a particular portion of a chromosome. The key to achieving the highest resolution in mapping a QTL is to choose markers that have the largest number of coinformative meioses. This is accomplished by selecting sets of markers that have numerous heterozygous parents (solid circles in Fig. 2) in common. Although any parent heterozygous for a marker contributes informative meioses to the map, they are only coinformative when the same parent is heterozygous for a second marker being employed. Thus, markers should be chosen by looking down a column of a particular parent (especially the WC boar that contributes 81 informative meioses when heterozygous) and picking markers that have solid circles and are thus coinformative. Summing the number of offspring for each parent heterozygous for all the chosen markers gives the total number of coinformative meioses. This is sufficient information to make rational marker selections for many applications, rather than using markers chosen arbitrarily by position. Data from other resource populations genotyped for these markers can be entered and included in similar diagrams, increasing the number of markers for which sufficient coinformative meioses are available. The mapping of QTLs in any re- 


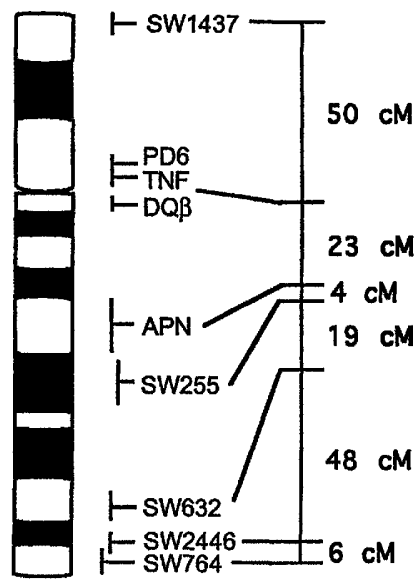

Figure 5 Comparison of physical and linkage maps of SSC7. The localizations from the FISH analysis are indicated by vertical bars. The genetic distance between the markers is taken from the data of Fig. 2 and is shown at the right.

source population will thus be greatly enhanced by entering the primary genotypic information for all populations in public data bases (Keele et al. 1994).

\section{Map Integration}

We describe the first example of directed integration of the cytogenetic and linkage maps of a livestock species. This approach is significantly more efficient than previous efforts to obtain anchor loci via screening of large insert libraries for microsatellites (Ellegren et al. 1994b; Hawkins et al. 1994), as it begins with a polymorphic marker at a known position in the linkage group. Polymorphic, cytogenetic anchors can be produced to assess coverage, orientation, and relative recombination rates or to aid in ordering of loci. Application of this approach has produced a comprehensive map of SSC7 and verified that it spans the entire chromosome.

\section{Recombination}

The physical assignment of markers SW632, SW255, SW2446, and SWR74 supports the overall orientation and order of markers in the linkage group, as well as demonstrating variation of recombination rate as a function of position along the chromosome. Map expansion at the terminal parts of many human chromosomes has been reported (Hartley et al. 1984; Donis-Keller et

\section{MAP OF SSC7 REVEALS SLA SPANS CENTROMERE}

al. 1987; Peterson et al. 1991; Helms et al. 1992; Ozelius et al. 1992). In addition, increased recombination at both telomeres of porcine chromosome 1 has been observed (Ellegren et al. 1994c). On SSC7, we observe that the recombination rate increases dramatically in the area near the q-arm telomere. The physical distance separating SW632 and SW764 is only $~ 15 \%$ of the chromosome length, yet the genetic interval is $36 \%$ of the linkage group. The situation at the p-arm terminus is less clear. Our data do not rule out the possibility that recombination also increases near the short-arm telomere, as we have not placed any physical markers between the PD6 and SW1437 anchors; however, the effect must be smaller because the 50-cM interval between these markers encompasses $\sim 30 \%$ of the chromosomal length. It thus appears that the recombination rate does not increase uniformly in the vicinity of telomeres or that the centromere has a depressive effect on recombination that extends for some distance outward along each chromosome arm, such that the long arm telomere has a higher rate than the short arm on this submetacentric chromosome.

\section{SLA Complex}

The close physical association of the three classes of genes in an MHC complex has been well conserved through evolution, suggesting that this association may have an important functional role (for review, see Klein 1986). The gene organization within this region also appears to be conserved between humans and swine, although a somewhat different organization of MHC genes has been observed in cattle and rodents. The bovine class II genes appear to be organized in two subregions that are $\sim 17 \mathrm{cM}$ apart (Andersson et al. 1988; Georges et al. 1990; van Eijk et al. 1993), although the overall order of gene classes is not known. In addition, the mouse and rat MHC contain class I genes on either side of the class II gene series (Widera and Flavell 1985). One possibility is that the genes of the MHC have been kept in close proximity through evolution to allow for coordinate regulation of gene expression. However, the gene coding for $\beta$-microglobulin, which forms a dimer with class I antigens at the cell surface, is unlinked to the MHC in most mammals studied to date and thus would not be subject to this form of coordinate expression.

The data in this report indicate that SLA function has not been prevented by the presence 


\section{T. SMITH ET AL.}

of the SSC7 centromere, as immune function of adult swine appears robust and autoimmune disease is uncommon. This suggests that the conservation of gene grouping within the complex is not attributable to a requirement for coordinate regulation of gene expression through some unidentified cis-acting mechanism that might be disrupted by the presence of the centromere complex (Klein 1986, 1991; Accolla 1991). An alternative hypothesis is that the association is a result of selective pressure to keep matched allelic groups together. As the $\beta$-microglobulin gene does not display polymorphism of the type observed for the class I and II genes, there is no selective pressure to keep it associated with the complex. The positioning of the SLA in a chromosomal region with a low rate of recombination is consistent with this hypothesis.

Finally, the association of the class III genes with the MHC is particularly difficult to explain, as many or most of these genes have no apparent functional association with each other or with the class I and II antigens. Thus, the need for coordinate regulation of these genes is not obvious. However, in the above hypothesis the association of the class III genes with the MHC may simply be a consequence of their positioning between the class I and II genes in the ancestral chromosome during early evolution of mammals. The selective pressure to keep the class I and II antigens in proximity may simply have "trapped" these genes in the complex.

\section{METHODS}

\section{Microsatellites}

Microsatellite markers bearing SW prefixes were isolated from M13 phage clone libraries as described (Rohrer et al. 1994). Primer sequences were checked against previously reported sequences and are given in Table 1 or are as described (Coppieters et al. 1993; Fredholm et al. 1993; Ellegren et al. 1994a; Robic et al. 1994; Rohrer et al. 1994; Ruyter et al. 1994; Wintero and Fredholm 1994; L.J. Alexander, G.A. Rohrer, and C.W. Beattie, in prep.). PCR protocols were as described (Rohrer et al. 1994).

\section{RFLP}

The hybridization probes used were PD6, a 1-kb XhoI-SalI genomic fragment (Ehrlich et al. 1987); PD7, a 450-bp BamHI-MspI genomic fragment (D. Singer, pers. comm.); Bf, a 500-bp BglII-KpnI genomic fragment (Peelman et al. 1991); steroid 21-hydroxylase (CYP21), a 3.4-kb EcoRIBamHI genomic fragment (Geffrotin et al. 1990); DRB, a 360-bp StuI-BamHI cDNA fragment (Pratt et al. 1990); DQB, a 300-bp EcoRI-BamHI cDNA fragment (Pratt et al. 1990); and DQA, a 600-bp XbaI-BamHI cDNA fragment (Sachs et al. 1988). Probes were labeled by the random priming method using a kit and manufacturers' protocols (Amersham). Porcine genomic DNA was digested, electrophoresed, transferred to Zetaprobe membrane, probed, and washed at $65^{\circ} \mathrm{C}$ as per the manufacturer's protocol (Bio-Rad). PCR-RFLP of DQB was performed as described (Shia et al. 1995).

\section{Genotyping}

Genotypes from the autoradiographs of Southern blots or PCR reactions were entered directly into the MARC data base (Keele et al. 1994). Error checking and data analysis using CRIMAP 2.4 (Green et al. 1989) were as described (Bishop et al. 1994; Keele et al. 1994; Rohrer et al. 1994).

\section{Cosmids}

The primers used for genotyping of microsatellites (Table 1 ; Rohrer et al. 1994) were employed in iterative screening isolations (Israel 1993) of cosmids bearing the markers. The PD6 cosmid was isolated with primers that amplify across exon 2 of the gene (Erlich et al. 1987) and were 5-GCCACCTTCACCACGGAC and 3'-TTGGACCCAGAAACGCAGG. The DQB cosmid was isolated with primers that amplify exon 2 of the gene (Shia et al. 1995). Cosmids isolated with primers for the TNF $\beta, D Q B$, and PD6 genes were verified by cycle sequencing with one or both of the primers used for the isolation, using a kit and manufacturers' protocols (New England Biolabs). The DQB cosmid was additionally checked with primers that amplify exon 3 of the gene: 5'-TGCGGTGACAGATTTCTATCC and 3'-ACGAGCACCTGGTAGGTCC.

\section{Cytogenetic Assignments}

FISH analysis of cosmids was conducted independently in at least two laboratories to confirm assignments. In addition, direct in situ single-copy (DISC)-PCR (Troyer et al. 1994) was employed to confirm the assignments of markers DQB, TNF, SW764, and SW1437. Somewhat different FISH protocols were employed in each laboratory. In one laboratory, metaphase chromosomes were obtained from 3-day-old pokeweed-stimulated porcine blood lymphocyte cultures. One hour before harvesting, colcemid was added to the cultures at a concentration of $0.3 \mu \mathrm{g} / \mathrm{ml}$. Cells were harvested, and air-dried metaphase spreads were prepared using standard methods. The chromosomes were banded before hybridization using the GTG technique (Godsen 1994). Metaphase spreads were selected, photographed, and destained before hybridization. Biotin-labeled (BRL) probe (100-120 $\mathrm{ng}$ ) of cosmid and 5-10 $\mu \mathrm{g}$ of sonicated porcine genomic competitior DNA were hybridized to the slides for $12-36 \mathrm{hr}$ at $37^{\circ} \mathrm{C}$, washed with $2 \times \mathrm{SSC}$ at $42^{\circ} \mathrm{C}$ for $15 \mathrm{~min}$, and visualized by two layers of fluoresceinavidin and one layer of biotinylated anti-avidin. Ten or more metaphase spreads were photographed for band designation. A variation of this standard protocol was employed by the other two laboratories (Lichter 1990). 


\section{ACKNOWLEDGMENTS}

We thank Richard Samson, Kevin Tennill, Kris Simmerman, and Renée Godtel for excellent technical assistance, Sherry Kluver for manuscript preparation, Penny Bures for photographic services, and Dr. John Keele for advice and communication of results prior to publication. We also thank Drs. Dinah Singer, Luc Peelman, David Sachs, and Claudine Geffrotin for providing SLA probes, and Drs. Dinah Singer and Roger Stone for critical review of the manuscript. Mention of a trade name, proprietary product, or specific equipment does not constitute a guarantee or warranty by the USDA and does not imply approval to the exclusion of other products that may be suitable. This manuscript was supported in part by National Institutes of Health grant P01-CA49488.

The publication costs of this article were defrayed in part by payment of page charges. This article must therefore be hereby marked "advertisement" in accordance with 18 USC section 1734 solely to indicate this fact.

\section{REFERENCES}

Accolla, R.S., C. Auffray, D.S. Singer, and J. Guardiola. 1991. The molecular biology of MHC genes. Immunol. Today 12: 97-99.

Andersson, L., A. Lunden, S. Sigurdardottir, C.J. Davies, and L. Rask. 1988. Linkage relationships in the bovine MHC region. High recombination frequency between class II subregions. Immunogenetics 27: 273-280.

Archibald, A.L., C.S. Haley, J.F. Brown, S. Couperwhite, H.A. McQueen, D. Nicholson, W. Coppieters, A. Van de Weghe, A. Stratil, A.K. Winterø, M. Fredholm, N.J. Larsen, V.H. Nielsen, D. Milan, N. Woloszyn, A. Robic, M. Dalens, J. Riquet, J. Gellin, J.-C. Caritez, G. Burgaud, L. Ollivier, J.-P. Bidanel, M. Vaiman, C. Renard, H. Geldermann, R. Davoli, D. Ruyter, E.J.M. Verstege, M.A.M. Groenen, W. Davies, B. Heyheim, A. Keiserud, L. Andersson, H. Ellegren, M. Johansson, L. Marklund, J.R. Miller, D.V. Anderson Dear, E. Signer, A.J. Jeffreys, C. Moran, P. Le Tissier, Muladno, M.F. Rothschild, C.K. Tuggle, D. Vaske, J. Helm, H.-C. Liu, A. Rahman, T.-P. Yu, R.G. Larson, and C.B. Schmitz. 1995. The PiGMaP consortium linkage map of the pig (Sus scrofa). Mamm. Genome 6: 157-175.

Bishop, M.D., S.M. Kappes, J.W. Keele, R.T. Stone, G.A. Hawkins, R. Fries, S. Solinas-Toldo, M.D. Grosz, S.L.F. Sunden, J. Yoo, L.V. Cundiff, and C.W. Beattie. 1994. A genetic linkage map for cattle. Genetics 136: 619-639.

Carroll, M.C., P. Katzman, E.M. Alicot, B.H. Koller, D.E. Geraghty, H.T. Orr, J.L. Strominger, and T. Spies. 1987. Linkage map of the human major histocompatibility complex including the tumor necrosis factor genes. Proc. Natl. Acad. Sci. 84: 8535-8539.

Coppieters, W., A. van de Weghe, L. Peelman, A. Depicker, A. van Zeveren, and Y. Bouquet. 1993. Characterization of porcine polymorphic microsatellite loci. Anim. Genet. 24: 163-170.

\section{MAP OF SSC7 REVEALS SLA SPANS CENTROMERE}

Donis-Keller, H., P. Green, C. Helms, S. Cartinhour, B. Weiffenbach, K. Stephens, T.P. Keith, D.W. Bowden, D.R. Smith, E.S. Lander, D. Botstein, G. Akots, K.S. Rediker, T. Gravius, V.A. Brown, M.B. Rising, C. Parker, J.A. Powers, D.E. Watt, E.R. Kauffman, A. Bricker, P. Phipps, H. Muller-Kahle, T.R. Fulton, S. Ng, J.W. Schumm, J.C. Braman, R.G. Knowlton, D.F. Barker, S.M. Crooks, S.E. Lincoln, M.J. Daly, and J. Abrahamson. 1987. A genetic linkage map of the human genome. Cell 51: 319-337.

Dunham, I., C.A. Sargent, J. Trowsdale, and R.D. Campbell. 1987. Molecular mapping of the human major histocompatibility complex by pulsed-field get electrophoresis. Proc. Natl. Acad. Sci. 84: 7237-7241.

Echard, G., M. Yerle, J. Gellin, M. Dalens, and M. Gillois. 1986. Assignment of the major histocompatibility complex to the p14-q12 region of chromosome 7 in the pig (Sus scrofa domestica L.) by in situ hybridization. Cytogenet. Cell Genet. 41: 126-128.

Edfors-Lilja, I., H. Ellegren, A.K. Winterø, M. Ruohonen-Lehto, M. Fredholm, U. Gustafsson, K. Kumar Juneja, and L. Andersson. 1993. A large linkage group on pig chromosome 7 including the MHC class I, class II (DQB), and class III (TNFB) genes. Immunogenetics 38: 363-366.

Ehrlich, R., R. Lifshitz, M.D. Pescovitz, S. Rudikoff, and D.S. Singer. 1987. Tissue specific expression and structure of a divergent member of a class $1 \mathrm{MHC}$ gene family. J. Immunol. 139: 593-602.

Ellegren, H., M. Johansson, B.P. Chowdhary, S. Marklund, D. Ruyter, L. Marklund, P.B. Nielsen, I. Edfors-Lilja, I. Gustavsson, R.K. Juneja, and L. Andersson. 1993. Assignment of 20 microsatellite markers to the porcine linkage map. Genomics 16: $431-439$.

Ellegren, H., B.P. Chowdhary, M. Johansson, L. Marklund, M. Fredholm, I. Gustavsson, L. Andersson. 1994a. A primary linkage map of the porcine genome reveals a low rate of recombination. Genetics 137: 1089-1100.

Ellegren, H., B. Chowdhary, M. Johansson, L. Andersson. 1994b. Integrating the porcine physical and linkage map using cosmid-derived markers. Anim. Genet. 25: 155-164.

Ellegren, H., B.P. Chowdhary, M. Fredholm, B. Høyheim, M. Johansson, P.B. Nielsen, P.D. Thomsen, and L. Andersson. 1994c. A physically anchored linkage map of pig chromosome 1 uncovers sex- and position-specific recombination rates. Genomics 24: 342-350.

Fredholm, M., A.K. Winter, K. Christensen, B. Kristensen, P.B. Nielsen, W. Davies, and A. Archibald. 1993. Characterization of 24 porcine (dA-dC)n-(dT-dG)n microsatellites: genotyping of unrelated animals from four breeds and linkage studies. Mamm. Genome 4: $187-192$.

Geffrotin, C., P. Chardon, D.F De Andres-Cara, R. Feil, C. 


\section{T. SMITH ET AL.}

Renard, and M. Vaiman. 1990. The swine steroid 21-hydroxylase gene (CYP21): cloning and mapping within the swine leucocyte antigen complex. Anim. Genet. 21: 1-13.

Geffrotin, C., C.P. Popescu, E. Cribiu, J. Boscher, C. Renard, P. Chardon, and M. Vaiman. 1984. Assignment of MHC in swine to chromosome 7 by in situ hybridization and serological typing. Ann. Genet. 27: 213-219.

Georges, M., M. Lathrop, Y. Bouquet, P. Hilbert, A. Marcotte, A. Shwers, J. Roupain, G. Vassart, and R. Hanse. 1990. Linkage relationships among 20 genetic markers in cattle. Evidence for linkage between two pairs of blood groups systems: B-Z and S-F/V respectively. Anim. Genet. 21: 95-105.

Gosden, J.R. (ed.) 1994. Methods in molecular biology, Vol. 29, Chromosome Analysis Protocol, Medical Research Council, Edinburgh, Scotland, pp. 55-56. Humana Press, Totowa, NJ.

Green, P., K. Falls, and S. Crooks. 1989. Documentation for CRI-MAP, version 2.4. Washington University School of Medicine, St. Louis, Mo.

Hartley, D.A., K.E. Davies, D. Drayna, R.L. White, and R. Williamson. 1994. A cytological map of the human X chromosome: Evidence for non-random recombination. Nucleic Acids Res. 12: 5277-5285.

Hawkins, G.A., S.S. Toldo, M.D. Bishop, S.M. Kappes, R. Fries, and C.W. Beattie. 1995. Physical and linkage mapping of the bovine genome using cosmids. Mamm. Genome 6: 249-254.

Helms, C., S.K. Mishra, H. Riethman, A.K. Burgess, S. Ramachandra, C. Tierney, D. Dorsey, and $\mathrm{H}$.

Donis-Keller. 1992. Closure of a genetic linkage map of human chromosome $7 \mathrm{q}$ with centromere and telomere polymorphisms. Genomics 14: 1041-1054.

Israel, D.I. 1993. A PCR-based method for high stringency screening of DNA libraries. Nucleic Acids Res. 21: $2627-2631$.

Johansson, M., H. Ellegren, and L. Andersson. 1995. Comparative mapping reveals extensive linkage conservation-but with gene order rearrangements-between the pig and the human genomes. Genomics 25: 682-690.

Jung, Y.C., M.F. Rothschild, M.P. Flanagan, L.L. Christian, and C.M. Warner. 1989. Association of restriction fragment length polymorphisms of swine leucocyte antigen class I genes with production traits of Duroc and Hampshire boars. Anim. Genet. 29: 79-91.

Keele, J.W., J.E. Wray, D.W. Behrens, G.A. Rohrer, S.L.F. Sunden, S.M. Kappes, M.D. Bishop, R.T. Stone, L.J. Alexander, and C.W. Beattie. 1994. A conceptual database model for genomic research. Computat. Biol. 1: $65-76$.
Klein, J. 1986. Natural history of the major

histocompatibility complex, John Wiley \& Sons, New York.

Klein, J., Z. Zhu, J. Gutkneckht, F. Figeuroa, and M. Kasahara. 1991. Mhc: Lessons in evolution. In Immunogenetics of the major histocompatibility complex (ed. R. Srivastava), pp. 18-38. Verlag Chemie Press, New York.

Kristensen, B., and A.L. de Weck. 1980.

Histocompatibility antigens (SLA) in swine. Possible correlation between SLA haplotypes and performance of piglets. Anim. Blood Groups Biochem. Genet. 11: 58-59.

Kuhnert, P., C. Wüthrich, E. Peterhans, and U. Pauli. 1991. The porcine tumore necrosis factor-encoding genes: genomic sequence and comparative analysis. Gene 102: $171-178$.

Lawrance, S.K., C.L. Smith, R. Srivastava, C.R. Cantor, and S.M. Weissman. 1987. Megabase-scale mapping of the HLA gene complex by pulsed field gel electrophoresis. Science 23: 1387-1390.

Lichter, P., C.C. Tang, K. Call, G. Hermanson, G.A. Evans, D. Housman, and D.C. Ward. 1990. High-resolution mapping of human chromosome 11 by in situ hybridization with cosmid clones. Science 247: 64-69.

Mallard, B.A., B.N. Wilkie, and B.W. Kennedy. 1989. Influence of major histocompatibility genes on serum hemolytic complement activity in miniature swine. Am. J. Vet. Res. 50: 359-363.

O'Brien, S.J., J.E., Womack, L.A. Lyons, K.J. Moore, N.A. Jenkins, and N.G. Copeland. 1993. Anchor reference loci for comparative genome mapping in mammals. Nature Genet. 3: 103-112.

Olsen, J., H. Sjostrom, and O. Noren. 1989. Cloning of the pig aminopeptidase $\mathrm{N}$ gene. Identification of possible regulatory elements and the exon distribution in relation to the membrane-spanning region. FEBS Lett. 251: $275-281$.

Ozelius, L.J., D.J. Kwiatkowski, D.E. Schuback, X.O. Breakfield, N.S. Wexler, J.F. Gusella, and J.L. Haines. 1992. A genetic linkage map of human chromosome $9 \mathrm{q}$. Genomics 14: 716-720.

Peelman, L.J., A.R. van de Weghe, W.R. Coppieters, A.J. van Zeveren, and Y.H. Bouquet. 1991. Cloning and sequencing of the porcine complement factor $\mathrm{B}$. Immunogenetics 34: 192-195.

Peterson, M.B., S.A. Slaugenhaupt, J.G. Lewis, A.C. Warren, A. Chakravarti, and S.E. Antonarakis. 1991. A genetic linkage map of 27 markers on human chromosome 21. Genomics 9: 407-419.

Poulsen, P.H., P.D. Thomsen, and J. Olsen. 1991. Assignment of the porcine aminopeptidase N (PEPN) 
gene to chromosome 7 cen-q21. Cytogenet. Cell Genet. 57: $44-46$.

Pratt, K., D.H. Sachs, S. Germana, M. El-Gamil, F. Hirsch, K. Gustafsson, and C. LeGuern. 1990. Class II genes of miniature swine II. Molecular identification and characterization of $B(\beta)$ genes from the SLA haplotype. Immunogenetics 31: 1-6.

Rabin, M., R. Fries, D. Singer, and F.H. Ruddle. 1985. Assignment of the porcine major histocompatibility complex to chromosome 7 by in situ hybridization. Cytogenet. Cell Genet. 39: 206-209.

Robic, A., M. Dalens, N. Woloszyn, D. Milan, J. Riquet, and J. Gellin. 1994. Isolation of 28 new porcine microsatellites revealing polymorphism. Mamm. Genome 5: $580-583$.

Rohrer, G.A., L. Alexander, J.W. Keele, T.P. Smith, and C.W. Beattie. 1994. A microsatellite linkage map of the porcine genome. Genetics 136: 231-245.

Ruyter, D., A.J.M. Verstege, J.J. van der Poel, and M.A.M. Groenen. 1994. Five porcine polymorphic microsatellites. Anim. Genet. 25: 53.

Sachs, D.H., S. Germana, M. El-Gamil, K. Gustafsson, F. Hirsch, and K. Pratt. 1988. Class II genes of the miniature swine. I. Class II gene characterization by RFLP and by isolation from a genomic library. Immunogenetics 28: 22-29.

Satz, M.L., L.-C. Wang, D.S. Singer, and S. Rudikoff. 1985. Structure and expression of two porcine genomic clones encoding class I MHC antigens. J. Immunol. 135: 2167-2175.

Schook, L.B., M.S. Rutherford, J.-K. Lee, Y.-C. Shia, M. Bradshaw, and J.K. Lunney. 1995. The swine major histocompatibility complex. In: The major histocompatibility complex of domestic animals (ed. L.B. Schook and S.J. Lamont), CRC Publication Inc., Boca Raton, FL (In press.)

Shia, Y.-C., M. Bradshaw, M.S. Rutherford, H.A. Lewin, and L.B. Schook. 1995. Polymerase chain reaction based genotyping for characterization of SLA-DQB and SLA-DRB alleles in domestic pigs. Anim. Genet. 26: $91-100$.

Singer, D.S., R. Ehrlich, H. Golding, M.L. Satz, L. Parent, and S. Rudikoff. 1988. Structure and expression of class 1 MHC genes in the miniature swine. In The molecular biology of the major histocompatibility complex of domestic animal species (ed. C.M. Warner, S.J. Lamont, and M.F. Rothschild), pp. 63-62. Iowa State University Press, Ames, IA.

Solinas, S., U. Pauli, P. Kuhnert, E. Peterhans, and R. Fries. 1992. Assignment of the porcine tumor necrosis factor alpha and $\beta$ genes to the chromosome region $7 \mathrm{p} 11-\mathrm{q} 11$ by in situ hybridization. Anim. Genet. 23: $267-271$.

\section{MAP OF SSC7 REVEALS SLA SPANS CENTROMERE}

Sood, A.K., D. Pereira, and S.M. Weissman. 1981. Isolation and partial nucleotide sequence of a cDNA clone for human histocompatiblity antigen HLA-B by use of an oligodeoxynucleotide primer. Proc. Natl. Acad. Sci. 78: 616-620.

Tissot, R.G., C.W. Beattie, and M.S. Amoss Jr. 1987. Inheritance of Sinclair swine cutaneous malignant melanoma. Cancer Res. 47: 5542-5545.

Troyer, D.L., D.W. Goad, H. Xie, G.A. Rohrer, L.J. Alexander, and C.W. Beattie. 1994. Use of direct in situ single-copy (DISC) PCR to physically map five porcine microsatellites. Cytogenet. Cell Genet. 67: 199-207.

Vaiman, M. 1989. Possible effects of the pig SLA complex on physiological performances. Curr. Top. Vet. Med. Anim. Sci. 52: 124-133.

Van Eijk, M.J.T., I. Russ, and H.A. Lewin. 1993. Order of bovine DRB3, DYA, and PRL determined by sperm typing. Mamm. Genome 4: 113-118.

Widera, G., and Flavell, R.A. 1985. The I region of the $\mathrm{C} 57 \mathrm{BL} / 10$ mouse: characterization and physical linkage to $\mathrm{H}-2 \mathrm{~K}$ of an SB $\beta$-like class II pseudogene, $\psi \mathrm{A} \beta 3$. Proc. Natl. Acad. Sci. 82: 5500-5504.

Winterø, A.K., and Fredholm, M. 1994. Three porcine polymorphic microsatellite loci (S0078, S0079, S0157) Anim. Genet. 25: 436.

Xu, Y., M.F. Rothschild, and C.M. Warner. 1992. Mapping of the SLA complex of miniature swine: Mapping of the SLA gene complex by pulsed field gel electrophoresis. Mamm. Genome 2: 2-10.

Yerle, M., Y. Lahbib-Mansais, C. Millink, Goureau, P. Pinton, G. Echard, J. Gellin, C. Zijlstra, N. De Haan, A.A. Bosma, B. Chowdhary, F. Gu, I. Gustavsson, P.D.

Thomsen, K. Christensen, G. Rettenberger, H. Hameister, A. Schmitz, B. Chaput, and G. Frelat. 1995. The PiGMaP consortium cytogenetic map of the domestic pig (Sus scrofa domestica) Mamm. Genome 6: 176-186.

Received July 26, 1995; accepted in revised form September 19, 1995. 


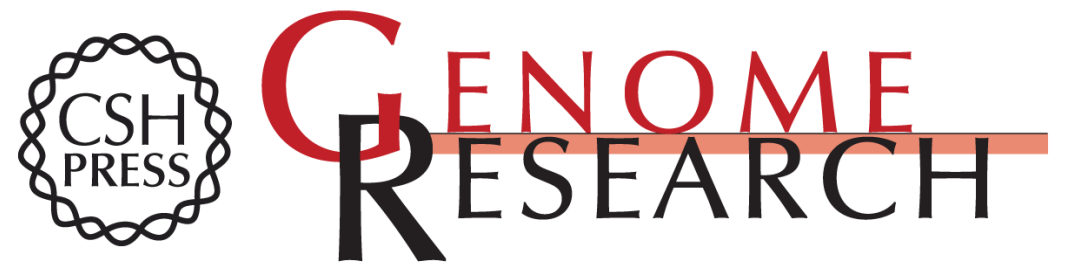

\section{Directed integration of the physical and genetic linkage maps of swine chromosome 7 reveals that the SLA spans the centromere.}

T P Smith, G A Rohrer, L J Alexander, et al.

Genome Res. 1995 5: 259-271

Access the most recent version at doi:10.1101/gr.5.3.259

References This article cites 55 articles, 11 of which can be accessed free at:

http://genome.cshlp.org/content/5/3/259.full.html\#ref-list-1

\section{License}

Email Alerting Receive free email alerts when new articles cite this article - sign up in the box at the Service top right corner of the article or click here.

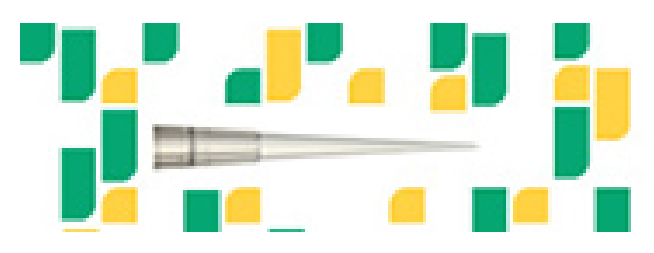

To subscribe to Genome Research go to: https://genome.cshlp.org/subscriptions 